\title{
The Cross-Sector Collaboration for Development Policy of Rural Creative Economy: The Case of Bengkoang Creative Hub
}

\author{
Slamet Rosyadi ${ }^{1}$, Ahmad Sabiq ${ }^{2}$, Abdul Aziz Ahmad ${ }^{3}$, Muhammad Yamin ${ }^{4}$ \\ ${ }^{1}$ Faculty of Social and Political Sciences, Universitas Jenderal Soedirman, Purwokerto Central Java, Indonesia \\ ${ }^{2}$ Faculty of Social and Political Sciences, Universitas Jenderal Soedirman, Purwokerto Central Java, Indonesia \\ ${ }^{3}$ Faculty of Economics and Business, Universitas Jenderal Soedirman, Jl HR Bunyamin Purwokerto Central Java, Indonesia \\ ${ }^{4}$ Faculty of Social and Political Sciences, Universitas Jenderal Soedirman, Purwokerto Central Java, Indonesia \\ ${ }^{1}$ Corresponding Author: slamet.rosyadi@unsoed.ac.id \\ doi) $h$ ttp://dx.doi.org/10.18196/jgpp.811339
}

Article Info: $\quad$ Abstract: This paper examines a cross-sector collaborative model for development policy in a creative economy in a rural area setting. The creative economy based on the village's creative potential is considered capable of contributing to the national economy, but it should be supported by public policies that are adaptive to the potential and needs of creative economy actors. The paper used a qualitative approach with case studies in Linggasari Village, Banyumas Regency, Central Java, Indonesia. The selected village in this study represents one of the leading creative economy subsectors in Indonesia, which is culinary. The study found that collaboration among Penta Helix forces played multiple roles in driving rural creative actors and building rural creative ecosystems. The stages of collaboration were identified in strengthening organizational structure, program implementation, and organizational consolidation. Organizational capability and innovation have been growing in rural creative economy actors during cross-sector collaboration implementation. This study provides insights into how Penta Helix collaborates with rural creative actors to promote the rural creative economy. From a public policy perspective, this study fills a significant gap in the literature regarding rural development models that are not covered much in the creative economy policy.

Keyword: Cross-Sector Collaboration; Development Policy; Creative Economy; Rural Area.

\section{INTRODUCTION}

Several researchers have reported the importance of the creative economy in promoting economic growth. (Daubaraite \& Startiene, 2015) found a significant effect of the creative economy on economic growth both at the national and international levels. Another study conducted by (Gouvea \& Vora, 2018) found that a well-developed creative economy sector affected increasing creative products' exports. In the Indonesian context, (Sukma et al., 2018) also reported a significant correlation between increased fashion exports and craft products to state income, society, and employment. Thus, the creative economy sector is one of the locomotives driving the economy and national economic growth.

In Indonesia, the Creative Economy Agency noted that the creative economy sector had experienced a significant increase in the last four years: IDR 852 billion (2015), IDR 894 billion (2016), IDR 990.4 billion (2017), 1,005 trillion (2018) (Okezone.com, 2018). Thus, the growth of the creative economy in the last four years has reached 9.5 percent and outshines the national economic growth, which only reaches an average of 5 percent.

From a public policy perspective, rural areas are not much discussed in creative economy policies. However, currently, the creative economy potential in rural areas has received serious attention from the government. Previously, village funds were allocated more for physical development. In the future, village funds will also be focused on developing the creative economy. Referring to the trend of national data regarding the creative economy's contribution, the government even believes that the creative economy based on the village's superior potential can contribute to the national economy (Radar Semarang, 2017). However, research on developing the creative economy in rural areas reports several governments and creative economy actors' challenges. First, access to creative economy actors in the village to get 
government resources is still minimal. They prefer to use social media resources and network access to promote their products (Suryana et al., 2019). Second, knowledge of Intellectual Property Rights (IPR) is still low because most creative economy actors have low education. They are more focused on marketing than the protection of IPR (Suryana et al., 2019). Third, the village government has not yet understood the concept of the creative economy, creative community, and its direct application in business (Marzaman, 2018). Fourth, there is less evidence on the influential role of multi-stakeholder partnership in developing the creative economy sector ((Muhyi et al., 2017); (Al-Tabbaa et al., 2019)). Therefore, cross-sector collaboration is still a challenging issue in the creative economy sector.

The lack of research results also shows research challenges in the creative economy policy field with rural loci. A study conducted by (Lee \& Wall 2014) reported that discourse on the 'creative economy' focused primarily on metropolitan areas and global cities, but little attention had been paid to the relevance of creativity to other urban and regional settings, particularly in rural areas. Though analysis conducted by (Townsend et al., 2017) demonstrated that the creative economy could grow within and contribute to rural areas as long as there is adequate broadband connectivity. Furthermore, according to (Roberts \& Townsend 2016), a creative economy is the key to rural growth. The public policy that the village needs are developing internet infrastructure to attract creative actors to develop in rural areas.

However, to date, most local governments in Indonesia do not yet have a creative economy development policy model at the rural level, and there is often confusion in the development of interagency creative economy programs (Dewandaru \& Purnamaningsih, 2017). This confusion has resulted in overlapping efforts to develop the creative economy to produce a satisfactory performance for creative economy actors, especially in rural areas.

Researching the model of creative economy development policy in rural areas can hopefully fill a village development policy model's shortcomings based on creative resource potential. The current development paradigm is creativity. Even creativity has been developed as the prime mover in the engine of economic growth (Lee \& Wall, 2014). By developing a creativity-based economic approach, the creative products produced in the village will be met with a broad market. So far, village development that is too physically oriented has widened economic disparities and unresolved poverty (Handra, 2018).

Theoretically, creative economy-based village development requires stakeholder support from various sectors. The reason is that village development using a partial approach is not effective in responding to increasingly complex socio-economic problems in rural areas. Revitalization and sustainability of rural areas' resources require an integrated mechanism to attract various external resources involved in rural development. This condition encourages the government to develop a collaborative governance model to create a conducive creative economic development climate in rural areas.

Collaboration is defined as "a cooperative, inter-organizational relationship that is negotiated in an ongoing communicative process" (Hardy et al., 2003). Conceptually, collaboration is distinguished from cooperation. According to (Gulati et al., 2012), cooperation is the "joint pursuit of an agreed-on goal(s) in a manner corresponding to a shared understanding of contributions and payoffs". Thus, the concept of collaboration contains a more strategic reach than cooperation. Collaboration is also a model of long-term cooperation involving several institutions to achieve agreed goals.

Collaboration shows voluntary cooperation between parties to realize one or more parties (Castañer \& Oliveira, 2020). Volunteering in collaboration means that there is an understanding that collaboration is in an informal and open situation. Collaboration is based on the principle of empowerment, especially for organizations that are newly developing or communities that need help from other parties. Openness in collaboration will ultimately facilitate more comprehensive social networking and cooperation with various stakeholders (Doitchinova \& Zaimova, 2015); (Esparcia, 2014); (Udimal et al., 2019).

The involvement of stakeholders in relevant collaborations is explained by network theory. Collaboration partners' role is to assess other parties' trust and the legitimacy of key stakeholders' involvement (Bryson et al., 2006). With more partners involved in the collaboration, the higher the level of trust and legitimacy will be. Thus, collaboration becomes a mirror of cooperation based on mutual trust and strengthening among stakeholders.

In some literature, the development of the creative economy requires the collaboration of the Penta Helix (Suryana et al., 2019); (Yunas, 2019); (Widowati et al., 2019); (Widjajani et al., 2018). Penta Helix's involvement in the creative economy sector is needed to encourage product and service innovation to provide higher added value (Sukarno et al., 2020). The creative economy that demands innovation requires increasing the capacity of the actors. Through Penta Helix's power, creative economy players get the transfer of knowledge and expertise needed to increase their competitiveness (Rosyadi et al., 2020). 
Penta Helix consists of academia, business, government, community, and media. These five forces play an essential role in facilitating the flow of resources needed to develop economic potential, especially in rural areas. Agriculture as a leading sector in rural areas requires multi-stakeholder collaboration within the framework of the creative economy. Several studies have shown that agricultural products processed with a creative economy approach will have a positive impact on the village economy (Janc et al., 2020); (Munro, 2016) \& (White, 2010).

Multi-stakeholder collaborations such as Penta Helix can be classified as cross-sector collaboration or partnership. According to (Bryson et al., 2006), cross-sector collaboration is "the linking or sharing of information, resources, activities, and capabilities by organizations in two or more sectors to achieve jointly an outcome that could not be achieved by organizations in one sector separately". The Penta Helix collaboration provides various resources to develop the creative economy in rural areas. With this flow of resources, creative economy actors' capacity in rural areas can develop to optimize rural resources' potential to develop the creative economy.

From the perspective of public policy theory, cross-sector collaboration becomes the choice of policymakers when the government approach is ineffective or fails to solve a public problem (Bryson et al., 2006). The complexity of public problems cannot be solved by government intervention alone. In the context of creative economic development, three main issues need the government's attention, namely creative places, creative people, and creative support (White, 2010). Creative places are related to the carrying capacity of areas needed by creative economy actors, such as transportation, road access, internet access, and environmental safety and comfort. Creative people are concerned with the talents possessed by creative economy actors. One of the critical issues regarding creative people is to retain talented owners to stay and develop in the village (White, 2010).

Meanwhile, creative support shows the network of cooperation needed by creative economy actors to increase their capacity. The government itself cannot carry out efforts to address these three main issues. Collaboration with various stakeholders is needed to formulate effective public policies in developing creative potential in rural areas (Bain \& McLean, 2012; Donald et al., 2013).

The author argues that collaboration can promote a creative economy's development policy in a rural area setting. The growing strength of Penta Helix consisting of academics, business, government, media, and communities can help develop the problems of the creative economy in rural areas (Widowati et al., 2019); (Widjajani et al., 2018); (Yunas, 2019). Penta Helix's contribution to the creative economy's development is to provide support and assistance in the early stages of creative business growth (Sudiana et al., 2020). However, evidence on it is still needed to explore to address the problems of cross-sector collaboration in the creative economy sector ((Muhyi et al., 2017); (Dewandaru \& Purnamaningsih, 2017)). Thus, this study examines the collaborative model as a policy strategy for developing a rural creative economy. With this test, this study fills a significant gap in the literature regarding rural development models that are not covered much in the creative economy policy.

\section{RESEARCH METHOD}

This research used a qualitative approach with a case study method. The qualitative approach is the most suitable method for understanding the perceptions and interactions that actors make concerning certain phenomena (Denzin \& Linclon, 2005). In this study, the phenomenon studied was the collaboration of actors in developing the creative economy. Case studies as a qualitative research strategy understand a complex social phenomenon (Yin, 2009). The case study method allows researchers to obtain holistic and meaningful information about the social phenomena being studied. The study location was in Linggasari Village, Kembaran District, Banyumas Regency. The location selection was based purposively because of the collaboration phase's uniqueness in developing the creative economy in rural areas, which were only recently discovered in the village. The research informants were selected purposively under two criteria: having knowledge and experience managing the creative economy sector. Informants consisted of creative economy actors, government practitioners, academics, business practitioners, and the creative community.

In-depth interviews are the primary data collection instrument to explore evidence related to collaboration between actors. The interview questions focused on answering three critical questions: (1) why does the local creative economy's development require multistakeholder collaboration? (2) what is the role of stakeholders in the creative economy development process? and (3) how the public policies that local governments have established to ensure the sustainability of creative economy development in rural areas? Various data 
published in online media news and official government documents complement the data and apply data triangulation.

Data were analyzed using thematic analysis. According to (Braun \& Clarke, 2006), researchers can use thematic analysis to find patterns or themes from the data collected. This method is suitable for this research because it intends to analyze the data to find the relationship between patterns in a collaborative phenomenon between stakeholders.

\section{The Case of Bengkoang Creative Hub}

\section{RESULT AND DISCUSSION}

Bengkoang Creative Hub $(\mathrm{BCH})$ is a youth village's creative community in Linggasari Village, Kembaran District, Banyumas Regency, Central Java. BCH seeks to develop a creative economy by using a local fruit known as Bengkoang or Jicama plant (the crisp, white-fleshed, edible tuber of the pea family's climbing plant), which is the main agricultural product of their village. So far, Jicama in Linggasari Village has been sold raw at the jicama market on the side of the village road.

BCH was founded because of the youth's concern about Jicama farmers' fate who often failed to harvest since their jicama fruit's shape was not round enough and was not suitable for sale in the market. Even the selling price is lower than the cost of harvesting. In the end, because of that crop failure, the jicama fields were only cleared, and new plants were planted again. As time went on, the creative youths found several ideas to process Bengkoang into processed products with higher economic value and tried to develop Linggasari village into a Bengkoang tourism village. It is what they aim for in establishing BCH. The following quotations are taken from the interview made with a creative youth and the village head related to their concerns towards the rural creative economy.

"BCH appeared before the 2020 Mid-Term Village Development Plan (RPJMDes) was drawn up after I won the third Pilkades. The development of BCH attracted me as the village head to incorporate the creative economy theme into the village development strategy policies. Moreover, I am developing the concept of one village one product (OVOP) with Bengkoang as its superior product. I want to raise jicama as raw material for creative products and not only sell them in the form of raw materials. Then, I see there is a common interest between the idea of OVOP and BCH which originally produced masks from Bengkoang ". (TP, 49 years old, head of the village, September 12, 2020).

"Initially, we were concerned about the failure of the Bengkoang farmers' harvest. Farmers discard the shape of the jicama that is not according to consumer tastes. From there, we tried to take advantage of this situation to manage the jicama that was disposed of as raw material for beauty masks. Fortunately, the farmers gave the jicama for free ". (MF, 18 years old, BCH organizer).

To develop creative products from jicama raw materials, $\mathrm{BCH}$ managers have encountered obstacles in allocating adequate raw materials and low prices. From interviews with creative community actors, it was revealed that the creative economy ecosystem has not fully supported $\mathrm{BCH}$ activities. The $\mathrm{BCH}$ institution, which was still new and managed by young people, did not have sufficient capacity to manage the creative economy. Although the enthusiasm to build a creative economy has grown, capacity strengthening is still needed so that they are consistent in developing BCH. Another challenge is that BCH's capital is still minimal, which can hinder the production process.

Realizing the still weak capacity of $\mathrm{BCH}$, the managers collaborate with creative communities that also play an active role in the district creative economy committee and other stakeholders such as academics and related regional offices, conveyed by $\mathrm{BCH}$ managers as follows. 
"Since the creative economy ecosystem has not yet been established, I am exploring several collaborations offered by the creative community, academics, entrepreneurs, and local governments. This collaboration helps BCH to gain knowledge, skills, and social networks with other institutions. BCH received training on product creation, tool assistance, and capital from community service activities organized by academics." (MF, 18 years old, BCH organizer).

The Bengkoang Creative Hub case shows that developing the creative economy in rural areas requires the creative economy ecosystem's support. The potential of creative economy available in rural areas requires farmers' readiness, creative economy managers' capacity, and stakeholders' support, especially the creative community, academics, and local government development agencies. The following describes the cross-sector collaboration that occurred in the $\mathrm{BCH}$ case.

\section{Cross-Sector Collaboration}

The creative economy developed by $\mathrm{BCH}$ requires cross-stakeholder collaboration involving many actors. This collaboration aims to accelerate the development of rural potential. To realize this development, BCH involves the community and government and synergistically involves the business world, academics, and the media, currently known as the Penta helix model. The Penta Helix model is a collaborative model that actively involves relevant stakeholders in development. This collaboration aims to build mutual understanding and commitment, expand networks between actors, and generate creativity in village development. The existing collaboration between Bengkoang Creative Hub's development stakeholders can be explained based on the research findings.

\section{Academics}

So far, two universities in Banyumas have played a role in empowering $\mathrm{BCH}$. They are the Faculty of Economics and Business, Jenderal Soedirman University (FEB Unsoed), and the Faculty of Agriculture, Muhammadiyah University of Purwokerto (FP UMP).

Those two universities' academics have played a role in providing needed knowledge and technology and providing equipment assistance as was done by the community service team from FEB Unsoed. Apart from holding accounting training and upgrading production technology to improve BCH's performance, they also handed production and processing machines in the form of a grater, cracker dough molding machine, drying cabinet, cracker slicing machine, and continuous sealer.

Meanwhile, the Faculty of Agriculture, Muhammadiyah University of Purwokerto, organized an annual program, the Village Partners Program, to increase processed products' added value by increasing innovations to more varied products. $\mathrm{BCH}$ activists received training at the Integrated Laboratory of the Faculty of Agriculture. They were introduced to innovations so that these products are more varied and attractive and can provide added value from existing products and become additional income for Linggasari Village people. Among them were training in making cakes and jams.

Unfortunately, the sustainability of the activities of these academics is still unclear. The community should be provided with training, capital, and machine assistance, and there needs to be mentoring regarding the sustainable business stages in the future.

\section{Business}

With the business community, there has been no fruitful collaboration between $\mathrm{BCH}$ and the big companies. BCH activists have contacted several prominent companies that produce jicama powder, such as Viva, Oriflame, Mustika Ratu, and Sari Ayu, and even companies from abroad to cooperate. However, after a while, only Viva replied to their email and asked them to send samples. At the first sample submission, Viva refused because it did not comply with its quality standards. Then, Viva sent a sample and asked BCH to make something similar to the sample they provided. BCH finally managed to make it with the same quality. However, until now, there has been no order from Viva. Meanwhile, with local businesses, BCH also does not 
have a good collaboration. Meanwhile, with small businesses, $\mathrm{BCH}$ has established good cooperation, especially in marketing its products to small shops and convenience stores around the village.

\section{Community}

With the community, BCH has collaborated well with the activist of the Creative Economy Committee of Banyumas Regency, Doni Prasetyo. Doni was the one who encouraged the formation of $\mathrm{BCH}$. BCH's interaction with Doni has generated many creative ideas and opened $\mathrm{BCH}$ 's horizons for further development. Doni was also the one who connected $\mathrm{BCH}$ with several parties, including the local government and universities in Banyumas. Also, the local community in Linggasari village strongly supported the establishment of BCH. Village youth saw $\mathrm{BCH}$ as a forum for youth activities to be creative, useful, and productive. Jicama farmers also supported the operation of $\mathrm{BCH}$, especially farmers who failed to harvest due to the shape of their jicama fruit. They had high hopes for BCH to use their jicama as the raw material of processed products because processed products do not require raw materials in good shape.

\section{Government}

Government elements involved in the collaboration are the Village Government and District Government. In this case, the related agencies in the district government are still minimally involved. Unfortunately, $\mathrm{BCH}$ has not received support from the regional people's representative council (DPRD).

The first agency involved in assisting $\mathrm{BCH}$ is the Regional Archives and Libraries (Dinarpusda) of Banyumas Regency, which is not a key actor in developing public policies in creative economy development. Dinarpusda has connected BCH with various parties such as the Village Government, District government, academics, and various related agencies. Through the Banyumas Literacy for Welfare Program (LIUKMAS), Dinarpusda initiated the development of the potential of $\mathrm{BCH}$ with book discussions and FGDs about Bengkoang. Furthermore, Dinarpusda also facilitated the implementation of entrepreneurship training through product packaging workshops and online marketing techniques.

Another local government agency involved in collaboration with $\mathrm{BCH}$ is the Regional Development Planning and Development Research Agency (Bapedalitbang). $\mathrm{BCH}$ is involved in focus group discussion activities to explore the jicama processing industry's development by reducing existing obstacles or constraints. It is because jicama has become an icon for Kembaran sub-district, especially Linggasari Village. Through this FGD, the local government has promised to assist in processing licensing certification for the household scale food/beverage industry, marketing, and capacity building for $\mathrm{BCH}$, scaled up to become a village-owned enterprise.

The village government is highly committed to developing BCH and has provided a lot of generous support. The village head has helped BCH expand the network with various actors and has planned to empower $\mathrm{BCH}$ to be integrated into the Village Long and Medium Term Development Plan (RPJMD) for the next five years.

\section{Media}

The mass media have so far played a role in encouraging and arousing public attention to $\mathrm{BCH}$. Several local mass media have published reports on $\mathrm{BCH}$. Their reports are about the Bengkoang market on Linggasari Village's roadside, which sells bengkoang or jicama raw materials and collaborative activities between BCH and other stakeholders. Thus, BCH has become well known and has caught policymakers' attention at the local level. Besides, there was some news about $\mathrm{BCH}$ on social media.

The following table and figure 1. describe how cross-sector collaboration operates and how Penta Helix actors interact with each other in carrying out their respective roles more precisely and comprehensively. 
Table 1. The Role of Penta Helix in Rural Creative Economy Development

\begin{tabular}{clll} 
No. & \multicolumn{1}{c}{ Penta Helix Actor } & \multicolumn{1}{c}{ Role } \\
\hline 1 & Academics & $\bullet$ & Empowering creative rural worker \\
2 & Business & $\bullet$ & Creating a business partnership \\
3 & Government & $\bullet$ & Formulating strategic rural creative economy policy and \\
& & & providing empowering programs \\
4 & Creative Community & - & Promoting creative development climate and social \\
& & & network \\
5 & Media & - & Promoting public attention towards BCH \\
\hline
\end{tabular}

Source: obtained from primary data

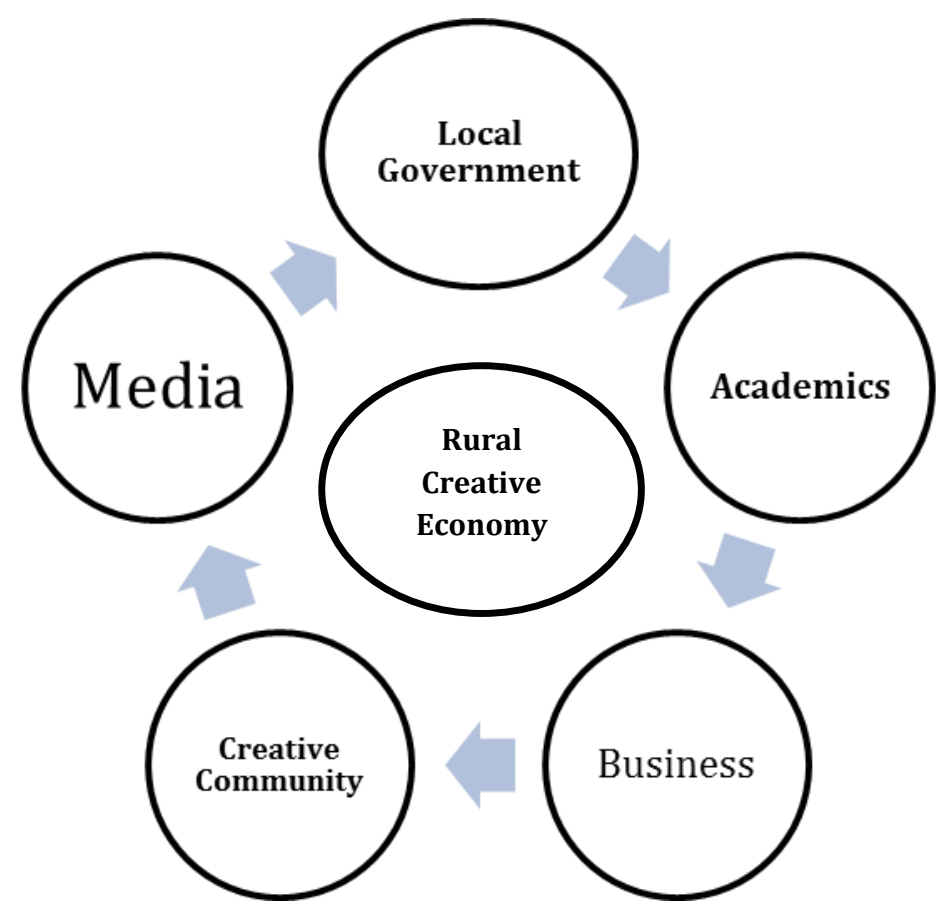

Figure 1. The cross-sector collaboration model of development policy for a rural creative economy

From Table 1. description, the collaboration between stakeholders has been going reasonably well and sustainably. However, in terms of business collaboration, BCH has been able to network with small business players but has not collaborated with large companies. The business sector is expected to play as an enabler to grow the economy of rural communities. Meanwhile, although not yet producing a massive reportage, the media have played a role as expected, which is as an expander in supporting promotions and creating a brand image.

From the academic circles, their role is empowering creative rural workers through research and community empowerment programs. However, there is a problem with sustainable mentoring. Their involvement is still limited. Indeed, many knowledge, technology, and skills have been conveyed to $\mathrm{BCH}$, but their follow-up is not visible enough to provide continuous assistance to BCH.

From the government side, $\mathrm{BCH}$ has been supported by some government agencies. However, there is no support from DPRD. Concerning policies, the role of the local council is crucial. Fortunately, there is a promising political will from the Banyumas district government, where the development of the rural creative economy has become a priority for regional development. Also, the village government's support for the sustainability of BCH is reliable.

In the meantime, the most visible support is coming from the community sector. The community has become an intermediary for BCH in connecting with several stakeholders and is the leading supporter of BCH's existence. The lack of support from other Penta Helix actors has resulted in $\mathrm{BCH}$ not performing well. For example, after attending the training pieces, $\mathrm{BCH}$ has indeed been able to make the right products in the form of crackers and jicama flour. However, they have difficulty in marketing. Until now, the products are still marketed around the village. In 16 | Slamet Rosyadi', Ahmad Sabiq², Abdul Aziz Ahmad ${ }^{3}$, Muhammad Yamin ${ }^{4}$ 
reality, $\mathrm{BCH}$ still needs mentoring to market its products. This collaboration has not yet targeted the second BCH's goal, namely Linggasari village's development as a Bengkoang tourist destination.

In the case of $\mathrm{BCH}$, cross-sector collaboration is crucial for the sustainable stage of $\mathrm{BCH}$ development. The study findings show that Penta Helix's role is divided into three stages of collaboration with BCH: strengthening the organizational structure, implementing programs, and consolidating it. In strengthening the organizational structure, village governments and creative communities play an essential role in facilitating $\mathrm{BCH}$ organizational restructuring and strengthening creative economy actors' commitment. This initial stage is crucial for $\mathrm{BCH}$ to build self-confidence due to actors' lack of experience managing the creative economy.

In the program's implementation phase, academics, business, and the media facilitate $\mathrm{BCH}$ with various technical capacity-building programs, market recognition, and promotion of BCH's existence. Academics who have the knowledge and expertise capital play a role in providing training programs needed by creative economy actors. Businesses open market information and access so that consumers know BCH products. Meanwhile, the media's power plays a role in introducing BCH's existence to the public.

The third stage is organizational consolidation. In this stage, the creative community plays a dominant role in uniting all the components and resources owned by $\mathrm{BCH}$. With extensive social networks, the creative community expands $\mathrm{BCH}$ access to support various parties such as the local government and local parliament. With more comprehensive support, $\mathrm{BCH}$ has more diverse resources for the future development of its organization. To conclude, the primary key to developing creative economists is the involvement of various actors in sharing roles, resulting in synergistic programs. To effectively promote creative economy development in a rural environment, the collaboration between these elements must be strong and good.

The interviews also show that developing a creative economy in rural areas is closely related to the local context and potential. Village heads, creative communities, and creative economy actors collaborate to take advantage of prospective opportunities from agricultural products, which are superior commodities. The potential for agricultural products that can be processed into various products encourages creative economy players to develop product diversification and agriculture-based creative tourism. Through their collaboration, agricultural products are processed using a creative economy approach and expected to raise the village economy. The results of this study confirm the findings of the study reported by Janc et al., 2020), (Munro, 2016), and (White, 2010).

Bengkoang (Pachyrhizus erosus) or jicama is an iconic agricultural product from Linggasari Village. Although Bengkoang production can be obtained throughout the year, not all farmers can obtain good quality Bengkoang. In 2013, many farmers experienced crop failure because the texture of the Bengkoang was not round, so it was not attractive to sell. Responding to this situation, some creative actors took advantage of the local jicama, which was not suitable for sale to be processed into products made from bengkoang raw materials such as masks. This action received support from the village head, interested in increasing the Bengkoang icon in the one village one product approach. The village head saw an excellent opportunity to develop jicama as a superior product and culinary tour.

To increase the added value of Bengkoang into other products, village heads and creative economy actors in the village are open to collaborating with other parties. The village head and the village's creative community realize that they do not have sufficient knowledge and expertise to develop agricultural product-based innovations. Therefore, they are open to working with various parties to process Bengkoang into innovative products. This openness facilitates social networking and collaborative partnerships with various stakeholders such as academics, district government, business, and creative communities to help develop the village's creative economy. The results of this study confirm the findings of other studies, including those (Doitchinova \& Zaimova, 2015), (Esparcia, 2014) and (Udimal et al., 2019).

The Penta Helix collaboration has had a significant impact on developing the creative economy in rural areas. Creative actors can develop creative and innovative products and services. Collaboration with various stakeholders facilitates the capacity building of rural 
creative economy actors. Besides obtaining new knowledge and techniques, the rural creative economy actors have received generous moral support from various parties. It also increases the motivation of rural creative actors to continue to develop their creative businesses. The support of the village government, which will increase the status of $\mathrm{BCH}$ to become a village-owned enterprise, provides more significant opportunities for the development of a rural creative economy. This study's results support the critical role of Penta Helix collaboration in village economic development, as found in a study by (Widowati et al., 2019) (Widjajani et al., 2018).

The crucial role of Penta Helix in developing the rural creative economy is found in three stages of collaboration, namely strengthening the organizational structure, implementing programs, and consolidating the organization. From an organizational development perspective, the newly developing $\mathrm{BCH}$ institutions need adequate capabilities to respond to increasingly complex environmental, social and economic challenges. It would be impossible for $\mathrm{BCH}$ to overcome this complexity without the support of other agencies. The lack of knowledge, experience, skills, and managerial abilities is a big challenge for $\mathrm{BCH}$ to manage its creative business. The growing strengths of Penta Helix provide an effective solution for $\mathrm{BCH}$ to overcome its organizational weaknesses. Penta Helix offers the resources BCH needs to develop innovation and organizational capacity to adapt to the changing environment. These findings corroborate a study conducted by (Al-Tabbaa et al. 2019), which examined alliance management capabilities in a cross-sector partnership framework. They prove that cross-sector collaboration can encourage a learning process to increase organizational capacity that cannot be obtained alone.

This study also found that to strengthen the development of the creative economy in villages. An effective public policy is needed to nurture creative classes and talents that grow in rural areas. The support of the village government and district governments through various development programs is the key to developing the creative economy in rural areas. In the context of this research, the village government shows great siding with the creative economy by including the creative economy theme in the medium-term development plan policy for five years. Likewise, at the district level, the determination of rural creative economy development has become a priority for regional development. Such policies are critical to ensure the commitment of local governments in sustainably developing a rural creative economy. These findings support the research conducted by (Bain \& McLean, 2012) and (Donald et al., 2013).

Ideally, Penta Helix's strengths are formulated in a planned way in the creative economy development program in rural areas. This study's findings are that the creative economy development policy is still partially designed, both by district and village governments. As shown in Figure 1, Penta Helix has an essential role in encouraging developing a creative economy in rural areas. In practice, these essential roles (as shown in Table 1) have not been integrated into a creative economy development policy or program in specific fields. In the case of BCH, although the creative community plays a role in bridging social networks with local government agencies, it has not yet been designed in a collaborative program. In other words, the creative economy development policy is still in each actor's work plan, especially district and village governments. By integrating Penta Helix's power, the creative economy ecosystem can be formed by maximizing the critical roles of Penta Helix in empowering the creative economy in rural areas.

\section{CONCLUSION}

The purpose of this study is to examine the collaboration model as a policy strategy for developing a rural creative economy. This study's findings indicate that cross-sector collaboration involving Penta Helix's strengths has made a significant contribution to the development of the rural creative economy. Penta Helix's roles in developing the creative economy help the creative class in rural areas develop their institutional capacity and social networks.

However, this study found that cross-sector collaboration was not designed in a rural creative economy empowerment policy or program. The actors, especially from the creative community and academics, are involved in collaboration with rural creative economy institutions with a spirit of volunteerism. Meanwhile, district and village governments do not yet have a collaborative mechanism to integrate their creative economy development plans. 
Thus, cross-sector collaboration takes place without a well-planned design. The collaboration process is more likely to be formed because of social networks facilitated by the creative community.

This study suggests local governments allocate adequate resources to affirm creative economy institutions at the stage of strengthening organizational structures. Collaboration between local governments and creative economy institutions such as BCH is carried out to provide formal recognition to creative economy actors. This policy will have a positive impact on the commitment and confidence of rural creative economy actors. A cross-sector collaboration involving Penta Helix should be planned systematically within the framework of rural and regional development planning so that various resources owned by the actor Penta Helix can be managed more effectively and efficiently to empower creative economy institutions in rural areas.

\section{REFERENCE}

Al-Tabbaa, O., Leach, D., \& Khan, Z. (2019). Examining Alliance Management Capabilities in Cross-Sector Collaborative Partnerships. Journal of Business Research, 101, 268-284. https://doi.org/10.1016/j.jbusres.2019.04.001

Bain, A., \& McLean, H. (2012). The Artistic Precariat. Cambridge Journal of Regions, Economy and Society, 6(1). https://doi.org/10.1093/cjres/rss020

Braun, V., \& Clarke, V. (2006). Using thematic analysis in Psychology. Qualitative Research in Psychology, 3(2), 77-101. https://doi.org/10.1191/1478088706qp063oa

Bryson, J. M., Crosby, B. C., \& Stone, M. M. (2006). The Design and Implementation of CrossSector Collaborations: Propositions from the Literature. Public Administration Review, 66(s1), 44-55. https://doi.org/10.1111/j.1540-6210.2006.00665.x

Castañer, X., \& Oliveira, N. (2020). Collaboration, Coordination, and Cooperation Among Organizations: Establishing the Distinctive Meanings of These Terms Through a Systematic Literature Review. Journal of Management, 46(6), 965-1001. https://doi.org/10.1177/0149206320901565

Daubaraitè, U., \& Startienè, G. (2015). Creative Industries Impact on National Economy in Regard to Sub-sectors. Procedia - Social and Behavioral Sciences, 213, 129-134. https://doi.org/10.1016/j.sbspro.2015.11.415

Denzin, N. K., \& Linclon, Y. S. (2005). Introduction: The Discipline and Practice of Qualitative Research. In: Denzin, N.K. and Lincoln, Y. S., Eds., Handbook of Qualitative Research, 3rd Edition. Sage, Thousand Oaks.

Dewandaru, B., \& Purnamaningsih, N. (2017). Strategi Dalam Memajukan Industri Kreatif Dan Pengembangan Ekonomi Lokal Sebagai Daya Tarik Wisata (Studi Pada Kesenian Jaranan Di Kota Kediri). Ekonika: Jurnal ekonomi universitas kadiri, 1(2). https://doi.org/10.30737/ekonika.v1i2.4

Doitchinova, J., \& Zaimova, D. (2015). Innovative rural development through networks and partnerships. Trakia Journal of Sciences, 13(Suppl.1), 282-293. https://doi.org/10.15547/tjs.2015.s.01.048

Donald, B., Gertler, M. S., \& Tyler, P. (2013). Creatives after the crash. Cambridge Journal of Regions, Economy and Society, 6(1), 3-21. https://doi.org/10.1093/cjres/rst040 
Esparcia, J. (2014). Innovation and networks in rural areas. An analysis from European innovative projects. Journal of Rural Studies, 34, 1-14. https://doi.org/10.1016/j.jrurstud.2013.12.004

Gouvea, R., \& Vora, G. (2018). Creative industries and economic growth: Stability of creative products exports earnings. Creative Industries Journal, 11(1), 22-53. https://doi.org/10.1080/17510694.2017.1416529

Gulati, R., Wohlgezogen, F., \& Zhelyazkov, P. (2012). The Two Facets of Collaboration: Cooperation and Coordination in Strategic Alliances. The Academy of Management Annals, 6(1), 531-583. https://doi.org/10.1080/19416520.2012.691646

Handra, H. (2018). Can "Village Fund" reduce poverty in Indonesia? https://crawford.anu.edu.au/news-events/events/12803/can-village-fund-reducepoverty-indonesia

Hardy, C., Phillips, N., \& Lawrence, T. B. (2003). Resources, Knowledge and Influence: The Organizational Effects of Interorganizational Collaboration*. Journal of Management Studies, 40(2), 321-347. https://doi.org/10.1111/1467-6486.00342

Janc, K., Raczyk, A., \& Dołzbłasz, S. (2020). Not Only in Cities: Creative Activities in Rural Areas with a Case Study of Lower Silesia. Quaestiones Geographicae, 39(2), 97-112. https://doi.org/10.2478/quageo-2020-0013

Lee, A. H., \& Wall, G. (2014). Food clusters, rural development and creative economy. Journal of Rural and Community Development, 9(4), 1-23.

Marzaman, A. (2018). Creative community in the framework of empowerment and capacity building of society. 1,14 .

Muhyi, H. A., Chan, A., Sukoco, I., \& Herawaty, T. (2017). The Penta Helix collaboration model in developing centers of flagship industry in Bandung City. Rev. Integr. Bus. Econ. Res., 6(1), 412-417.

Munro, E. (2016). Developing the Rural Creative Economy 'from Below': Exploring Practices of Market-Building amongst Creative Entrepreneurs in Rural and Remote Scotland. $M / C$ Journal, 19(3). https://doi.org/10.5204/mcj.1071

Okezone.com. (2018). Pendapatan Ekonomi Kreatif Diprediksi Tembus Rp1.200 Triliun di 2019. https://economy.okezone.com/read/2018/12/20/320/1993774/pendapatan-ekonomikreatif-diprediksi-tembus-rp1-200-triliun-di-2019

Radar Semarang. (2017). Pertumbuhan Ekonomi Kreatif Pedesaan Terus Digenjot. https://radarsemarang.com/2017/12/08/pertumbuhan-ekonomi-kreatif-pedesaanterus-digenjot/

Roberts, E., \& Townsend, L. (2016). The Contribution of the Creative Economy to the Resilience of Rural Communities: Exploring Cultural and Digital Capital. Sociologia Ruralis, 56(2), 197-219. https://doi.org/10.1111/soru.12075

Rosyadi, S., Kusuma, A. S., Fitrah, E., Haryanto, A., \& Adawiyah, W. (2020). The MultiStakeholder's Role in an Integrated Mentoring Model for SMEs in the Creative Economy 
Sector. SAGE Open, 10(4), 215824402096360. https://doi.org/10.1177/2158244020963604

Sudiana, K., Sule, E. T., Soemaryani, I., \& Yunizar, Y. (2020). Discovering Support Needed for Startups in their Early Stages Using on Penta Helix Framework. Business: Theory and Practice, 21(1), 212-221. https://doi.org/10.3846/btp.2020.10930

Sukarno, G., Rasyidah, R., \& Saadah, K. (2020). Improve Creative Industry Competitiveness Penta Helix and Human Capital in Digital Era. Proceedings of the 2nd International Media Conference 2019 (IMC 2019). 2nd International Media Conference 2019 (IMC 2019), Surabaya, Indonesia. https://doi.org/10.2991/assehr.k.200325.014

Sukma, M., Hartono, D., \& Prihawantoro, S. (2018). The Impacts Analysis of Creative-Products $\begin{array}{llll}\text { Export on the } \quad \text { Economy. JEJAK, 11(1), } & \text { 92-107. }\end{array}$ https://doi.org/10.15294/jejak.v11i1.11337

Suryana, S., Yuliawati, A. K., \& Rofaida, R. (2019). Developing the Business Performance of the Digital Creative Industry: Corporate Entrepreneurship Approach. GATR Journal of Business and Economics Review, 4(4), 171-179. https://doi.org/10.35609/jber.2019.4.4(4)

Townsend, L., Wallace, C., Fairhurst, G., \& Anderson, A. (2017). Broadband and the creative industries in rural Scotland. Journal of Rural Studies, 54, 451-458. https://doi.org/10.1016/j.jrurstud.2016.09.001

Udimal, T. B., Jincai, Z., \& Gumah, I. A. (2019). Dynamics in rural entrepreneurship - the role of knowledge acquisition, entrepreneurial orientation, and emotional intelligence in network reliance and performance relationship. Asia Pacific Journal of Innovation and Entrepreneurship, 13(2), 247-262. https://doi.org/10.1108/APJIE-03-2019-0021

White, P. (2010). Creative industries in a rural region: Creative West: The creative sector in the Western Region of Ireland. Creative Industries Journal, 3(1), 79-88. https://doi.org/10.1386/cij.3.1.79_1

Widjajani, W., Fajarwati, A., Hidayat, A., \& Haryadi, D. (2018). Quadruple Helix Innovation Model for Rural Development: The Case of Sukaraja Tourist Village in Indonesia. SOSIOHUMANITAS, 20(2), 1-10. https://doi.org/10.36555/sosiohumanitas.v20i2.106

Widowati, S., Ginaya, G., \& Triyuni, N. N. (2019). Penta Helix Model to Develop Ecotourism. International Journal of Social Sciences and Humanities, 3(2), 31-46. https://doi.org/10.29332/ijssh.v3n2.288

Yin, R. K. (2009). Case Study Research: Design and Methods. SAGE.

Yunas, N. S. (2019). Implementasi Konsep Penta Helix dalam Pengembangan Potensi Desa melalui Model Lumbung Ekonomi Desa di Provinsi Jawa Timur. Matra Pembaruan, 10. 